\title{
KESINONIMAN DALAM BAHASA INDONESIA
}

\author{
E. Zaenal Arifin \\ Universitas Indraprasta PGRI \\ Email: zaenalarifin 48@yahoo.com \\ Blog: zaenalarifin28.wordspress
}

\begin{abstract}
Reviews of synonymy in Indonesian is aimed to describe the various issues related to equality of words in our national language. The method used is qualitative descriptive method. The theoretical framework of this review is based on the opinion of D.A. Cruse in Lexical Semantics, and other Semantics expert opinion. Retrieved complex description of synonymy in this language, i.e. absolute synonym, cognitive synonym, plesionym, partial synonym, and congruous synonym. Synonyms are used so there are variations that sentence constructed by the words will be able to make it live and concrete the use of one's language so that the communication between speachers will be more attractive.
\end{abstract}

Key words: absolute synonym, cognitive synonym, plesionim, partial synonym, and congruous synonym

\begin{abstract}
ABSTRAK
Ulasan tentang "Kesinoniman dalam Bahasa Indonesia" ini bertujuan mendeskripsikan berbagai hal yang berkaitan dengan persamaan kata dalam bahasa nasional kita. Metode yang digunakan adalah metode deskriptif kualitatif. Kerangka teori ulasan ini bersandar pada pendapat D.A. Cruse dalam Lexical Semantics, dan pendapat para pakar semantik yang lain. Diperoleh deskripsi kesinoniman dalam bahasa Indonesia, yaitu (a) sinonim mutlak, (b) sinonin kognitif, (c) plesionim, (d) sinonim parsial, dan (e) sinonim selaras. Sinonim digunakan agar terdapat variasi sehingga kalimat yang dibangun oleh kata-kata itu dapat menghidupkan dan mengonkretkan pemakaian bahasa seseorang sehingga komunikasi antarpenutur akan lebih menarik.
\end{abstract}

Kata kunci: sinonim mutlak, sinonim kognitif, plesionim, sinonim parsial, dan sinonim selaras

\section{PENDAHULUAN \\ Latar Belakang}

Makna yang notabene sebagai wakil pikiran dan perasaan manusia, menurut (Kridalaksana, 1993:132), adalah maksud pembicara atau penulis yang mengharapkan orang lain dapat memahami apa yang dimaksud oleh pembicara melalui makna tersebut (Lih. KBBI, 2013:548). Betapa rumitnya menjalin komunikasi apabila bahasa yang digunakan tidak memiliki makna. Demikian juga, betapa rumitnya jika kata yang memiliki makna tersebut tidak dipahami lawan bicara sehingga antara penutur yang satu dan yang lain tidak bisa saling memahami. Misalnya, seseorang yang hanya bisa berbahasa Indonesia (tidak bisa berbahasa Inggris) tidak akan mampu berkomunikasi secara lancar dengan seseorang yang hanya mampu berbahasa Rusia (tidak bisa berbahasa Inggris pula). Dengan demikian, makna dalam sebuah bahasa dapat ditentukan oleh manusia berdasarkan kesepakatan yang sifatnya konvensional dan sesuai dengan perkembangan pikiran pemakainya.

Semantik sebagai ilmu yang mempelajari makna di dalam bahasa bermanfaat bagi kita yang ingin mempelajari suatu bidang tertentu. Manfaat semantik bagi seorang wartawan, reporter, atau seseorang yang berkecimpung dalam dunia persuratkabaran dan pemberitaan, misalnya, mempelajari semantik bertujuan mengetahui makna kata yang tepat untuk 
mendukung berita yang akan disampaikan kepada pembaca atau masyarakat umum. Manfaat bagi seorang penulis adalah dia dapat menyusun kalimat dan memilih kata yang maknanya tepat sehingga tulisannya dapat dipahami pembacanya. Lain halnya manfaat semantik bagi seorang guru. Sang guru akan menyampaikan materi ajar kepada siswanya dengan baik, dan siswanya akan memahaminya dengan baik pula karena Pak Guru menggunakan kalimatkalimat yang pilihan katanya tepat sesuai dengan makna yang dikandung oleh kata-kata tersebut. Jadi, manfaat semantik lebih bersifat praktis sehingga informasi yang disampaikan kepada masyarakat pembaca atau pendengar mudah dipahami.

\section{Rumusan Masalah}

Cruse (1995) membuat klasifikasi kesinoniman menjadi lima macam, yaitu (a) sinonim mutlak dengan skala kesinoniman, (b) sinonin kognitif, (c) plesionim, (d) sinonim parsial, dan (e) sinonim selaras. Berdasarkan klasifikasi versi Cruse tersebut, hal-hal yang perlu ditelaah lebih komprehensif, terutama implementasinya dalam bahasa Indonesia, adalah sebagai berikut.

1) Apa yang dimaksud dengan sinonim mutlak yang berskala?

2) Apa yang dimaksud dengan sinonim kognitif?

3) Bagaimana wujud plesionim itu?

4) Mengapa ada sinonim parsial?

5) Bagaimana eksistensi sinonim selaras?

\section{Tujuan Ulasan}

Dengan mengacu rumusan masalah di atas, tujuan ulasan ini adalah

1) ingin mendeskripsikan sinonim mutlak yang berskala;

2) akan menguraikan konsep sinonim kognitif;

3) ingin menjelaskan wujud plesionim;

4) ingin mengungkap sinonim parsial;

5) akan memaparkan sinonim selaras.

\section{KAJIAN PUSTAKA}

Ihwal kesinoniman dalam bahasa Inggris diklasifikasi dan dibahas secara terperinci dalam Lexical Semantics Cet. ke-5 oleh Cruse (1995:265-293) dengan disertasi contohcontoh penggunaannya. Klasifikasi tersebut dapat diterapkan ke dalam bahasa Indonesia walaupun ada perbedaan nuansa di sana-sini. Selain pendapat Cruse (1995), dalam ulasan ini dimanfaatkan juga pendapat linguis lain yang membahas kesinoniman, seperti Ullman (1964), Lyons (1977), Kridalaksana (1993), Verhaar (1993), Djajasudarma (1993), dan Karim dkk. (2013).

Kosakata dalam bahasa Indonesia, seperti halnya kosakata dalam bahasa apa pun di dunia, pada dasarnya saling berhubungan antara kata yang satu dan kata yang lain. Dengan demikian, kosakata dasar dalam bahasa Indonesia yang berjumlah lebih dari 100.000 lema atau entri (Kamus Besar Bahasa Indonesia Cet. VII, Edisi IV, Maret 2013), juga saling berkaitan. Bahkan, kosakata yang memiliki komponen makna yang sama atau mirip, kesalinghubungannya sangat erat, yang disebut relasi makna (sense relations). Misalnya, leksem kuda memiliki relasi makna dengan leksem binatang atau leksem mangga memiliki relasi makna dengan leksem buah-buahan (Cruse, 1995). Selanjutnya, Cruse (1995:23--49) membedakan relasi (hubungan) makna, yang disebutnya juga relasi leksikal (lexical relations), menjadi dua macam, yaitu relasi paradigmatik dan relasi sintagmatik.

Hubungan paradigmatik adalah hubungan asosiatif antarkata yang bisa saling menggantikan dalam suatu konstruksi. Dalam sebuah kalimat, misalnya, terdapat kata-kata yang bisa saling menggantikan dengan syarat fungsi, kategori, dan perannya sama dalam 
kalimat tersebut. Arah hubungan paradigmatik bersifat vertikal (arah atas-bawah). Misalnya, kalimat Petani mencangkul tanah di kebun. Kata petani dalam kalimat tersebut bisa digantikan dengan kata pedagang atau jurnalis yang sama-sama berfungsi sebagai subjek, dan sama-sama berkategori nomina, serta sama-sama berperan sebagai pelaku. Kemudian, kata mencangkul bisa digantikan oleh kata menjual atau menulis yang sama-sama berfungsi predikat, sama-sama berkategori verba, dan sama-sama berperan tindakan. Kata tanah bisa digantikan dengan kata pakaian atau berita yang sama-sama berfungsi objek, sama-sama berkategori nomina, dan sama-sama berperan sasaran. Frasa di kebun bisa digantikan dengan frasa di pasar atau dalam majalah yang sama-sama berfungsi sebagai keterangan, dan samasama berkategori frasa preposisi, serta sama-sama berperan sebagai tempat. Dengan demikian, secara paradigmatik, kalimat Petani mencangkul tanah di kebun dapat diganti dengan kalimat Pedagang menjual pakaian di pasar, atau Jurnalis menulis berita dalam majalah.

Adapun hubungan sintagmatik adalah hubungan struktural yang bersifat linear. Arah hubungan sintagmatik bersifat horizontal (arah kiri-kanan). Pemakai bahasa harus dapat menyusun kalimat dengan tertib agar pendengar atau pembaca dapat memahaminya dengan baik. Misalnya, kalimat Petani mencangkul tanah di kebun tidak bisa dideretkan ke kanan secara sembarangan menjadi Di petani kebun tanah mencangkul atau Kebun mencangkul di petani tanah walaupun jumlah katanya sama, yaitu lima buah.

Cruese (1995) memberikan gambaran perbedaan hubungan sintagmatik dan paradigmatik sebagai berikut.

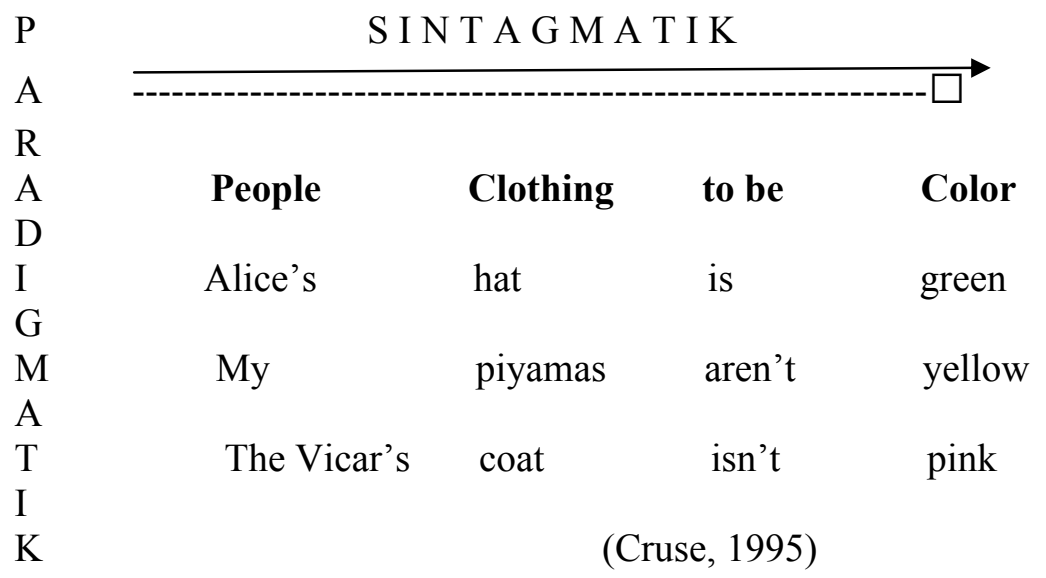

Hubungan makna di antara berbagai leksem dalam suatu bahasa menurut Cruse (1995) ada tujuh macam, yaitu menyangkut sinonimi (kesamaan makna), antonimi (kebalikan makna), polisemi (kegandaan makna yang jelas), ambiguitas (kegandaan makna yang membingungkan), hiponimi (ketercakupan makna), homonimi (kelainan makna), dan redundansi (kelebihan makna). Dalam tulisan ini akan diulas satu hal saja, yaitu kesinoniman.

Secara etimologis, kata sinonim berasal dari bahasa Yunani Kuno syn 'dengan' dan onoma 'nama'. Jadi, sinonim adalah dua kata atau lebih yang memiliki makna sama (Cruse, 1995:156). Sementara itu, Verhaar (1992) mengatakan bahwa sinonim adalah ungkapan (kata, frasa, kalimat) yang maknanya kurang lebih sama dengan makna ungkapan lain, misalnya bunga, kembang, dan puspa; mati, wafat, meninggal, dan tewas; jelek dan buruk (Lihat Karim dkk., 2013). Menurut Kridalaksana (1993:204), jika suatu kata dapat disubstitusi (diganti) dengan kata lain dalam konteks yang sama dan makna konteks tidak berubah, kedua kata itu dapat dikatakan bersinonim. Sementara itu, (KBBI, 2013:1315) menjelaskan bahwa sinonim adalah bentuk bahasa yang maknanya mirip atau sama dengan bentuk bahasa lain; muradif; kesinoniman 1) perihal sinonim; hubungan antara sinonim; 
kesinoniman kalimat adalah persamaan pengertian antara dua kalimat atau lebih; 2) sinonimi adalah hubungan antara bentuk-bentuk bahasa yang mirip atau sama maknanya.

Sinonim adalah hubungan semantik yang menyatakan adanya kesamaan makna antara satu satuan ujaran dan satuan ujaran lainnya. Relasi sinonim ini bersifat dua arah. Maksudnya, kalau satu satuan ujaran A bersinonim dengan satuan ujaran B, tentu satuan ujaran B itu bersinonim dengan satuan ujaran A. Secara konkret, kalau kata jelek bersinonim dengan kata buruk, dengan demikian, kata buruk juga bersinonim dengan kata jelek. Contoh lain, kata benar bersinonim dengan kata betul, dan kata betul juga bersinonim dengan benar (Karim dkk., 2013).

Menurut Cruse (1995), kata-kata jarang sekali benar-benar bersinonim. Bahkan, pakar tersebut berpendapat bahwa change the structure of the sentence, substitute one synonym for another, and the whole effect is destroyed.

Hubungan sinonimi ditandai oleh kemampuan dua leksem yang bisa saling menggantikan sebagai pengisi gatra di dalam kalimat tanpa mengubah makna. Sinonim yang tidak mengubah makna itu disebut sinonim mutlak (absolute synonym). Namun, sinonim mutlak jarang sekali ditemukan dalam bahasa karena setiap kata memiliki makna tersendiri. Seperti juga dikatakan oleh Cruse (1995) dan pakar-pakar semantik yang lain, In contemporary linguistics it has become almost axiomatic that complete synonymy does not exist. Each linguistic form has a constant and specific meaning. If the forms are phonemically different we suppose that their meanings are different. We suppose that there are no actual synonyms". Maksudnya, 'di dalam linguistik kontemporer terdapat aksioma bahwa kesinoniman yang mutlak tidak pernah ada. Kata atau ungkapan yang memiliki struktur fonemis yang berbeda dipastikan akan memiliki makna yang berbeda. Oleh karena itu, tidak ada kata-kata/ungkapan yang benar-benar bersinonim'. Dengan demikian, walaupun katakata/ungkapan yang bersinonim memiliki kesamaan makna, makna tersebut tidak seluruhnya sama (Adelin, 2013:3). Jadi, kata-kata/ungkapan yang berbeda secara fonemis, maknanya juga berbeda walaupun perbedaannya hanya dalam nuansa.

Menurut Soedjito (1989), sinonimi adalah persamaan arti atau makna, atau dua kata atau lebih yang memiliki makna sama. Sinonim ialah dua kata atau lebih yang maknanya (1) sama atau (2) hampir sama atau mirip. Misalnya, dua kata atau lebih yang mempunyai makna sama, yaitu buku - kitab, telinga-kuping, dapat-bisa, ayah-bapak, pintar-cerdas, dan sebagainya. Adapun dua kata atau lebih yang mempunyai makna hampir sama (mirip) adalah semua - seluruh - segala; cinta - kasih - sayang, mati - meninggal - wafat-gugur, dan sebagainya.

Dalam hal sinonim yang sama dan sinonim yang mirip, Kridalaksana (1993) berpendapat bahwa dalam bahasa Indonesia terdapat salah satu dari dua kata atau lebih yang maknanya mirip, tetapi bukan sinonim; misalnya kata bantuan dan pertolongan. Beliau menyebut gejala tersebut sebagai sinonim dekat (near-synonym, homonym, pseudosynonym). Lain lagi dengan pendapat Verhaar (1992:394), sering dikatakan bahwa kata-kata yang bersinonim memiliki makna yang sama, hanya bentuk-bentuknya berbeda. Verhaar menegaskan bahwa sebenarnya hubungan antarsinonim ialah bahwa ada perbedaan nuansa, dan maknanya dapat dikatakan 'kurang lebih sama'.

Djajasudarma (1993) menyatakan bahwa sinonim digunakan untuk menyatakan sameness of meaning 'kesamaan arti'. Hal tersebut dilihat dari kenyataan bahwa para penyusun kamus menunjukkan sejumlah perangkat kata yang memiliki makna sama; semua bersifat sinonim, atau satu sama lain sama makna, atau hubungan di antara kata-kata yang mirip (dianggap sama) maknanya.

Palmer dalam Djajasudarma (1993:40) memerinci sinonim sebagai berikut.: 
(1) Sinonim yang salah satu katanya berasal dari bahasa daerah atau bahasa asing. Misalnya, konde dan sanggul, domisili dan kediaman, khawatir dan gelisah.

(2) Sinonim yang pemakaiannya bergantung pada laras bahasa. Misalnya, dara, gadis, dan cewek; mati, meninggal, dan wafat.

(3) Sinonim yang berbeda makna emotifnya, tetapi makna kognitifnya sama. Misalnya, negarawan dan politikus; ningrat dan feodal.

(4) Sinonim yang pemakaiannya terbatas pada kata tertentu. Misalnya, busuk, basi, tengik, asam dan apek bermakna yang sama, 'buruk', tetapi tidak dapat saling menggantikan.

(5) Sinonim yang maknanya kadang-kadang tumpang tindih. Misalnya, bumbu dan rempahrempah; bimbang, cemas, dan sangsi; nyata dan kongkret.

Sinonim selain bisa disebut persamaan kata juga dapat dikatakan sebagai padanan kata. Misalnya:

ahli $=$ pakar $;$ akseleras $i=$ percepatan $;$ akurat $=$ saksama $;$

andal = tangguh; anemia $=$ kurang darah; anjung = panggung;

antagonis $=$ berlawanan; anulir $=$ abolisi; aplikasi $=$ pelaksanaan;

boga = makanan; bonafide = dapat dipercaya; bromocorah $=$ residivis;

dehidrasi $=$ kehilangan cairan tubuh; demisioner = habis masa jabatan;

dominasi $=$ penguasaan; donasi = bantuan; dosis = takaran;

eksibisi $=$ pertunjukan; ekskavasi $=$ penggalian; ekspansi $=$ perluasan;

ekstensi = perluasan; elaborasi = penjelasan terperinci; embargo = larangan;

epilog=penutup; estetika $=$ keindahan $;$ estimasi $=$ perkiraan; etos $=$ pandangan hidup;

fauna $=$ hewan; fenomena=kenyataan; flora=tanaman; forum =lembaga;

harmonis $=$ serasi; hayati $=$ hidup; hedonisme $=$ hura-hura;

inheren $=$ melekat $;$ injeks $i=$ suntik $;$ insinuas $i=$ sindiran $;$ insting $=$ naluri

instruktur $=$ pelatih; interaks $=$ hubungan; iterasi $=$ perulangan

klarifikasi $=$ penjelasan; klimaks $=$ titik puncak;

konsensus $=$ mufakat $;$ konservasi $=$ perlindungan; korelasi $=$ hubungan; krusial $=$ penting

manunggal $=$ bersatu; mayapada $=$ dunia $;$ mediator $=$ perantara $;$ misteri $=$ rahasia $;$

paradoksal $=$ kontras; pioner $=$ perintis.

Bentuk bahasa atau ungkapan yang memiliki persamaan makna itu dapat berupa morfem dengan morfem, kata dengan kata, frasa dengan frasa, dan sebagainya.

(a) Sinonim morfem (bebas) dengan morfem (terikat), seperti dia dan -nya.

(b) Sinonim kata dengan kata, seperti antara mati dan meningal; buruk dan jelek; bunga dan puspa, dan sebagainya.

(c) Sinonim kata dengan frasa atau sebaliknya. Misalnya, meninggal dan tutup usia; besar kepala dan sombong,

(d) Sinonim frasa dengan frasa. Misalnya, ayah ibu dan orang tua; meninggal dunia dan berpulang ke rahmatullah.

(e) Sinonim kalimat dengan kalimat, seperti Adik menendang bola dengan Bola ditendang Adik.

\section{HASIL ULASAN}

\section{Sinonim Mutlak yang Berskala}

Sinonim mutlak adalah pasangan kata yang mengandung semacam kemiripan semantik satu sama lain. Ullmann (1964:142--143) dalam Djajasudarma (1993) berpendapat 
bahwa sinonim mutlak masih memiliki skala atau derajat kesinoniman, yang terdiri atas sembilan macam, yaitu berupa

(1) yang menonjolkan makna emotif, misalnya mungil dan kecil; bersih dan ceria; hati kecil dan hati nurani;

(2) yang bersifat mencela atau tidak membenarkan, misalnya boros dan tidak hemat; hebat dan dahsyat;

(3) yang memiliki makna lebih umum (generik), misalnya menghidangkan dan menyediakan;

(4) yang memiliki makna lebih intensif, misalnya jenuh dan bosan; kejam dan bengis; imbalan dan pahala;

(5) yang lazim dipakai dalam bahasa percakapan, misalnya kayak dan seperti; ketek dan ketiak; (6) yang dipakai dalam bahasa kanak-kanak, misalnya pipis dan berkemih; mimik dan minum; bobo dan tidur;

(7) yang dipakai di daerah tertentu, misalnya cabai dan lombok; sukar dan susah; lepau dan warung; katak dan kodok; sawala dan diskusi.

(8) yang menjadi istilah bidang tertentu, misalnya plasenta dan ari-ari; ordonansi dan peraturan; disiarkan dan ditayangkan; dan

(9) yang banyak dipakai dalam ragam tulis, misalnya selalu dan senantiasa; enak dan lezat; lalu dan lampau.

Sinonim mutlak dalam bahasa Indonesia, sebenarnya, dapat berupa

(1) sinonim lengkap dan mutlak, misalnya surat kabar dan koran;

(2) sinonim lengkap dan tidak mutlak, misalnya orang dan manusia;

(3) sinonim tidak lengkap dan mutlak, misalnya wanita dan perempuan;

(4) sinonim tidak lengkap dan tidak mutlak, misalnya gadis dan cewek.

Jadi, sinonim absolut (absolute synonym) adalah pasangan kata atau frasa yang memiliki makna benar-benar sama dalam segala konteks. Akan tetapi, tidak ada sinonim yang benar-benar punya makna yang sama dalam semua konteks atau level sosial suatu Bahasa.

\section{Sinonim Kognitif (Cognitive Synonym)}

Yang dimaksud dengan sinonim kognitif adalah kata-kata yang memiliki kelas kata atau fungsi sintaksis yang sama, seperti nomina atau verba, yang dalam satu konteks kalimat maknanya sama, tetapi dalam konteks yang lain maknanya tidak sama, seperti kategori nomina: violin dan fiddle. Perhatikan dua kalimat di bawah ini.

1. He plays a violin very well.

2. He plays a fiddle very well.

Dalam kedua kalimat tersebut, baik kata violin maupun fiddle termasuk alat musik gesek (stringed musical instruments) yang memiliki makna biola. Akan tetapi, kata violin dan fiddle sendiri memiliki perbedaan dalam cara memainkannya, yaitu kalau violin dimainkan dalam bentuk musik klasik (classical music) sedangkan fiddle dimainkan dalam musik rakyat (folk music). Oleh karena itu, dalam semantik tidak ada yang disebut sinonim penuh (full synonym).

Contoh sinonim kognitif lain yang berupa verba adalah pass away dan die. Perhatikan dua kalimat di bawah ini.

3. My grandfather passed away yesterday.

4. My grandfather died yesterday.

Dalam kedua kalimat tersebut, baik kata passed away maupun died sama-sama memiliki makna 'meninggal dunia', 'mati', 'berpulang ke rahmatullah', dan sebagainya. Akan tetapi, ada sedikit perbedaan dari segi kondisi makna tersebut, yaitu kata passed away maknanya lebih halus (terhormat) daripada kata died yang agak kasar. 


\section{Plesionim}

Plesionim adalah jenis sinonim yang menegaskan sesuatu, sekaligus menyangkal sesuatu yang lain, seperti dalam kalimat berikut.

He is by no means fearless, but he's extremely brave

Jadi, plesionim atau 'hampir sinonim' adalah pasangan kata atau frasa yang menghasilkan kalimat dengan kondisi kebenaran yang berbeda. Plesionim adalah pasangan kata atau frasa yang berbeda pada Capital trait, tetapi sama dalam Subordinate traits.

Misalnya, ungkapan sakit hati (lever) harus diobati dokter bedah yang berbeda maknanya dengan sakit hati yang bersifat kejiwaan, yang harus diobati dengan keikhlasan dan memaafkan oraang yang menyakiti" kita. Sebenarnya, kedua pasang ungkapan tersebut hanya memiliki kesamaan fonologis, dan tidak memiliki kesamaan semantis.

\section{Sinonim Selaras}

Menurut Cruse (1995), sinonim selaras terjadi pada sinonim kognitif dan plesionim yang saling berhubungan. Dalam sinonim kognitif dan plesionim terdapat korelasi (hubungan) keselarasan, bahkan berkorelasi sempurna. Secara sederhana, sinonim selaras adalah beberapa kata atau ungkapan yang memiliki komponen makna yang sama, tetapi satu di antaranya memiliki komponen makna yang agak luas (berkaitan dengan luas dan sempitnya makna). Kadang-kadang dalam satu kelompok unsur yang bersinonim terdapat satu kata sebagai atasan dan dua atau lebih unsur sebagai hiponimnya. Misalnya, kata kuda dapat dianggap sebagai atasan (hiperonim) dari kuda jantan, kuda betina, dan anak kuda sebagai bawahannya (hiponim). Demikian juga, kata buah-buahan memiliki makna yang selaras dengan mangga, salak, pepaya, dan melon. Untuk kelompok kata-kata tersebut kata buah-buahan dapat dijadikan sebagai atasan (hiperonim), sedangkan kata-kata mangga, salak, pepaya, dan melon berstatus sebagai hiponimnya.

Kata senjata memiliki acuan yang lebih luas daripada kata bedil karena makna senjata telah mencakupi makna pisau, bedil, atau pistol atau senjata tidak hanya terdiri atas ketiga jenis benda yang disebutkan terakhir itu. Sebaliknya, pistol pasti termasuk jenis senjata dan begitu pula halnya dengan bedil dan pisau. Perhatikan contoh berikut.

(1) Semua pengunjung tidak boleh membawa senjata. (termasuk pisau, bedil, pistol)

(2) Semua pengunjung tidak boleh membawa pistol. (tidak termasuk pisau dan bedil)

Kata yang lebih luas acuannya disebut kata umum, seperti senjata, sedangkan kata yang lebih khusus acuannya disebut kata khusus, seperti pisau, golok, dan bedil.

Contoh kata umum lainnya adalah kendaraan. Kata itu memiliki acuan lebih luas daripada kata motor. Yang termasuk kendaraan tidak saja motor, tetapi juga sepeda, dokar, andong, mobil, pesawat, dan kereta api. Sebaliknya, mobil pastilah jenis kendaraan. Kata kendaraan memiliki acuan lebih luas (kata umum), sedangkan kata mobil dan kereta api memiliki acuan lebih khusus (kata khusus).

Kesinoniman dalam bahasa Indonesia berlaku pada pasangan kata umum dan kata khusus aatau pengacuan generik dan spesifik. Ayam, angsa, bebek, dan burung termasuk segolongan, yaitu golongan unggas. Jadi, kata unggas bersifat umum (generik), sedangkan ayam, angsa, bebek, dan burung adalah kata khusus (spesifik).

Dalam pembahasan lain, kata atau ungkapan umum (generik) sering disebut atasannya atau hipernim, sedangkan kata atau ungkapan khusus (spesifik) sering disebut bawahan atau hiponimnya.

\section{Sinonim Parsial}

Cruse (1995) menyebutkan adanya kesinoniman parsial, yaitu kesinoniman yang ditandai oleh kemampuan dua leksem yang saling menggantikan pada gatra kalimat khusus. 
Di dalam bahasa Indonesia, misalnya, terdapat kata $a b u$ dan debu. Mari kita bandingkan kalimat berikut.

1 a. Atap rumahnya tertutup $a b u l * d e b u$ vulkanik Merapi.

b. *Abu/debu jalanan beterbangan.

Pada kalimat (1a) kata debu terasa tidak tepat digunakan, tetapi pada kalimat (1b) kata $a b u$ justru yang tidak tepat karena secara semantis makna keduanya tidak identik. Perhatikan bahwa abu rokok terterima, tetapi *debu rokok terasa janggal. Keduanya tidak bersinonim mutlak karena maknanya tidak benar-benar identik.

Di samping klasifikasi kesinoniman seperti di atas, kesinoniman juga dapat diklasifikasi berdasarkan komponen maknanya sebagai berikut.

\section{a. Hubungan Kesamaan (identity)}

Sinonim jenis hubungan kesamaan terjadi karena dua kelas (kelas A dan kelas B) mempunyai komponen makna yang sama dan kedua kelas itu terdapat dalam sintaktis yang sama. Pada kalimat deklaratif keduanya ekuivalen ketika menjadi pengisi X. Di dalam bahasa Inggris, Cruse (1995), seperti sudah dibahas di atas, mencontohkan kata fiddle dan violin seperti pada kalimat

(1) He plays fiddle very well.

Kalimat itu memperikutkan dan diperikutkan makna

(2) He plays violin very well.

karena makna kedua kata itu benar-benar identik walaupun, sebenarnya, dalam konteks lain kedua alat musik tersebut berbeda makna secara halus, yaitu alat musik rakyat dan alat musik gesek.

\section{b. Hubungan Tumpang Tindih (overlap)}

Hubungan tumpang tindih terjadi karena ungkapan A dan ungkapan B memiliki komponen makna yang sama, tetapi ungkapan A memiliki komponen makna yang tak terdapat pada ungkapan B. Perhatikan bahwa makna abu rokok terasa mengandung proses perubahan dari rokok menjadi sisa hasil bakaran. Akan tetapi, proses perubahan menjadi sisa hasil bakaran seperti itu tidak dimiliki oleh makna kata debu. Itu sebabnya abu rokok dan $a b u$ gosok (sisa bakaran sekam padi) berterima, tetapi *debu rokok dan *debu gosok (terasa janggal).

\section{c. Hubungan Derajat (Bertingkat)}

Dua buah ujaran yang bersinonim maknanya tidak akan persis sama. Ketidaksamaan itu terjadi karena berbagai faktor, antara lain faktor waktu, faktor tempat atau wilayah, faktor keformalan, faktor sosial, faktor bidang kegiatan, faktor nuansa makna. Perhatikan uraian berikut ini. (Karim dkk., 2013:35-42).

Pertama, faktor waktu. Misalnya kata hulubalang bersinonim dengan kata komandan. Akan tetapi, kata hulubalang memiliki pengertian klasik, sedangkan kata komandan tidak memiliki pengertian klasik. Dengan kata lain, kata hulubalang hanya cocok digunakan pada konteks yang bersifat klasik. Sebaliknya, kata komandan tidak cocok untuk konteks klasik.

Kedua, faktor tempat atau wilayah. Misalnya, kata saya dan kata abdi adalah dua buah kata yang bersinonim. Namun, kata saya dapat digunakan di mana saja, sedangkan kata $\boldsymbol{a b d i}$ hanya cocok untuk masyarakat Sunda Jawa Barat, atau dalam konteks masyarakat yang berasal dari daerah Bandung. 
Ketiga, faktor keformalan. Misalnya, kata uang dan duit adalah dua buah kata yang bersinonim. Namun, kata uang dapat digunakan dalam ragam formal dan takformal, sedangkan kata duit hanya cocok untuk ragam tidak formal.

Keempat, faktor sosial. Misalnya, kata saya dan kata $\boldsymbol{a k} \boldsymbol{u}$ adalah dua buah kata yang bersinonim. Akan tetapi, kata saya dapat digunakan oleh siapa saja dan kepada siapa saja, sedangkan kata $\boldsymbol{a k} \boldsymbol{u}$ hanya dapat digunakan terhadap orang yang sebaya, yang dianggap akrab, atau kepada yang lebih muda atau lebih rendah kedudukan sosialnya.

Kelima, bidang kegiatan. Misalnya, kata matahari dan kata surya adalah dua buah kata yang bersinonim. Namun, kata matahari bisa digunakan dalam kegiatan apa saja, atau dapat digunakan secara umum, sedangkan kata surya hanya cocok digunakan pada ragam khusus. Terutama dalam ragam sastra.

Keenam, faktor nuansa makna. Misalnya, kata-kata melihat, melirik, menonton, meninjau, dan mengintip adalah sejumlah kata yang bersinonim. Namun, di antara yang satu dengan yang lainnya tidak selalu dapat dipertukarkan, karena masing-masing memiliki nuansa makna yang tidak sama. Kata melihat memiliki makna umum; kata melirik memiliki makna melihat dengan sudut mata; kata menonton memiliki makna melihat untuk kesenangan; kata meninjau memiliki makna melihat dari tempat yang jauh; dan kata mengintip memiliki makna melihat dari atau melalui celah sempit. Dengan demikian, jelas kata menonton tidak dapat diganti dengan kata melirik karena memiliki nuansa makna yang berbeda, meskipun kedua kata itu dianggap bersinonim.

Dari keenam faktor yang terurai di atas, dapat disimpulkan, bahwa dua buah kata yang bersinonim tidak akan selalu dapat dipertukarkan atau disubsitusikan. (Karim, 2013:17-41). Faktor lain adalah, ketidakberterimaan sebuah kalimat akibat faktor semantik bisa terjadi karena makna sebuah kata, atau juga pada makna keseluruhan kalimat. Misalnya, kesalahan dalam memilih kata (diksi), kesalahan faktual, kesalahan secara semantik dan sosial, kesalahan karena bermakna ganda (ambuguitas) dan kesalahan penggunaan kata ganti yang tidak jelas. Perhatikan beberapa contoh berikut ini.

(1) Ayam tetangga meninggal karena keracunan.

Kalimat di atas tidak berterima karena kesalahan memilih kata (diksi) dari satu rangkaian kata yang bersinonim, yaitu mati, wafat, dan pulang ke rahmatullah.

\section{Beberapa Kendala dalam Penggunaan Kesinoniman}

Pilihan kata atau diksi merupakan unsur yang sangat penting dalam berbahasa, baik dalam bahasa tulis, seperti untuk karang-mengarang, maupun dalam bahasa lisan seharihari. Pilihan kata bertujuan agar dalam menyatakan sesuatu, pemakai bahasa harus memilih kata dengan tepat. Untuk itu, pemakai bahasa dapat memanfaatkan kamus karena kamus memuat makna kata dengan benar.

Seperti sudah dibahas pada bagian terdahulu, tidak semua kata bersinonim dapat saling menggantikan dalam sebuah kalimat dan dapat digunakan dalam setiap kesempatan. Hal tersebut disebabkan oleh adanya satu atau dua komponen makna yang tidak sama, atau penggunaannnya dalam konteks tertentu tidak sama, atau karena turunan katanya tidak sama. Misalnya, kata bisa bersinonim dengan kata dapat, seperti tampak dalam kalimat Ia bisa naik sepeda dan Ia bisa naik sepeda. Akan tetapi, setelah dijadikan kata turunan dengan ditambahkan imbuhan yang sama ke-an, misalnya, menjadi kebisaan dan kedapatan, ternyata artinya sangat berjauhan. Di samping itu, budaya masyarakat pengguna bahasa, terutama yang berkaitan dengan sopan santun dan masalah tabu merupakan kendala dalam penggunaan kata yang bersinonim. Dalam hubungan itu, menurut Lyons (1996:132), suatu tuturan tidak berterima (unacceptable) karena alasan sosial-budaya. Misalnya, mungkin suatu tuturan tergolong tabu atau tidak layak secara sosial budaya, seperti die 'mati' yang seharusnya pass away 'meninggal'. Jika seseorang mengucapkan die dalam kalimat (1) His father ?died last 
nihgt 'ayahnya mati tadi malam' mungkin dapat berterima bagi pendengar tertentu, misalnya karena yang mengucapkan kaimat itu bukan anak kandung ayah yang meninggal itu. Namun, jika die itu diucapkan oleh anak kandung ayah yang meninggal (2) My father died last night, pendengarnya akan menganggap bahwa anak tersebut tidak tahu diri dan tidak memiliki rasa hormat kepada ayahnya. Jadi, tuturan tersebut dianggap takberterima dalam budaya masyarakat itu. Tuturan takberterima (3) ?My father died last night harus dikoreksi menjadi (3a) My father passed away last night karena di dalam masyarakat bahasa tertentu, penggunaan die terlarang dikatakan untuk mengungkapkan makna 'mati' bagi anggota keluarga sendiri. Namun, tidak berarti bahwa di dalam lingkungan tersebut ketakberterimaan tuturan (3) My father died last night itu menjadi takbermakna. Ketakberterimaannya lebih didasarkan pada makna sosial dan bukan didasarkan pada makna deskriptif (Lyons 1977:104).

Karena ada sesuatu yang melanggar tata sopan santun atau norma budaya penutur setempat, kalimat seperti itu takberterima. Misalnya, kalimat (4) Karena dilanda banjir, ikan dalam kolam saya habis hanyut, tinggal dua ekor, yang satu cewek yang satu laki takberterima dalam komunikasi normal, kecuali dalam lawakan.

\section{Manfaat Kesinoniman dalam Bahasa}

Sinonim digunakan untuk mengalih-alihkan pemakaian kata pada tempat tertentu agar kata yang digunakan bervariasi sehingga kalimat yang dibangun oleh kata-kata itu tidak membosankan. Kata-kata yang bersinonim akan dapat menghidupkan dan mengonkretkan pemakaian bahasa seseorang sehingga lewat bahasa tercapailah komunikasi yang jelas dan menarik. Dalam hal itu, pemakai bahasa dapat memilih kata yang paling tepat untuk digunakannya agar sesuai dengan kebutuhan (konsep) yang hendak disampaikannya dan sesuai dengan situasi yang dihadapinya. Simaklah contoh pemakaian kata lilit dan belit serta cerdas dan cerdik berikut ini.

(1) Sampai tua ia selalu dililit utang.

(1a) Sampai tua ia selalu dibelit utang.

(2) Anak laki itu cerdas benar, hasil belajar selalu baik.

(2a) Anak laki itu cerdik benar, hasil belajar selalu baik.

Kedua pasangan kata itu bersinonim, tetapi keduanya tidak persis sama. Dililit utang terasa bahwa utang lebih mungkin bisa diselesaikan, tetapi dibelit utang terasa lebih ruwet dan lebih sulit keluar dari keadaan berutang itu. Cerdas mengilatkan makna 'pintar dan tangkas', tetapi cerdik terkesan menunjukkan makna 'pintar, tetapi sedikit agak berakal kancil'.

Berkenaan dengan kesinoniman ada beberapa hal yang perlu diperhatikan. Pertama tidak semua kata dalam bahasa Indonesia mempunyai sinonim. Misalnya, kata beras, salju, batu, dan kuning tidak memiliki sinonim. Kedua ada kata-kata yang bersinonim pada bentuk dasar, tetapi tidak pada bentuk jadian. Misalnya kata benar dengan kata betul, tetapi kata kebenaran tidak bersinonim dengan kata kebetulan. Ketiga ada kata-kata yang tidak mempunyai sinonim pada bentuk dasar, tetapi memilki sinonim pada bentuk jadian. Misalnya kata jemur tidak mempunyai sinonim, tetapi kata menjemur mempunyai sinonim, yaitu mengeringkan, dan berjemur bersinonim dengan berpanas. Keempat ada kata-kata yang dalam arti sebenarnva, tidak mempunyai sinonim. arti kiasan justru mempunyai sinonim seperti pada contoh kata hitam dalam makna sebenarnya tidak ada sinonimnya, tetapi dalam arti kiasan ada sinonimnya. yaitu gelap. mesum. buruk dan lain-lain. 


\section{SIMPULAN}

Dengan berlandaskan kerangka teori yang dikemukakan Cruse (1995) dan para pakar semantik yang lain, seperti Lyons (1977), Ullman (1964), dan Verhaar (1999), sinonim adalah bentuk bahasa yang maknanya mirip atau sama dengan bentuk lain, baik kata, frasa, maupun bentuk kalimat, hanya lazimnya sinonim berlaku kata. Pada hemat saya, kesinoniman dalam bahasa Indonesia dapat diklasifikasi berdasarkan berbagai kriteria dan sudut pandang sesuai dengan pendapat keempat pakar tersebut, yaitu sebagai berikut.

Pertama, hubungan antarkata dalam kesinoniman berdasarkan komponen maknanya ada tiga macam, yaitu hubungan kesamaan, hubungan tumpang tindih, dan hubungan derajat. Kedua, dari segi jenisnya, kesinoniman dalam bahasa Indonesia terdiri atas lima jenis, yaitu (a) sinonim mutlak, (b) sinonin kognitif, (c) plesionim, (d) sinonim parsial, dan (e) sinonim selaras. Ketiga, berdasarkan kategorinya, terdapat kesinoniman nomina, verba, adjektiva, dan adverbial.Keempat, kesinoniman dalam bahasa Indonesia dapat berupa (a) sinonim antarkalimat, (b) sinonim antarfrasa, (c) sinonim antarkata, dan (d) sinonim antarmorfem. Kelima, kendala kesinoniman menyangkut beberapa hal, yaitu (1) kategori, (2) komponen makna, ((3) sopan santun, (4) budaya, (5) makna konotasi-denotasi, dan (6) makna konkretabstrak. Keenam, kata atau ungkapan yang bersinonim akan dapat menghidupkan dan mengonkretkan pemakaian bahasa seseorang dan tercapailah komunikasi yang menarik karena kata atau ungkapan. yang digunakan bervariasi sehingga kalimat yang dibangun tidak membosankan. 


\section{DAFTAR PUSTAKA}

Adelin, Cucu dkk. 2014. Sinonimi. Universitas Indraprasta PGRI: Pascasarjana.

Aminuddin. 1988. Semantik Pengantar Studi tentang Makna. Bandung. CV Sinar Baru

Chaer, Abdul. 1994. Linguistik Umum. Jakarta: Rineka Cipta.

Comrie, Bernard. 1976. Aspect. Cambridge: Cambridge University Press.

Cruse, D.A. 1995. Lexical Semantics. Cambridge University Press.

Departeman Pendidikan dan Kebudayaan. 2013. Kamus Besar Bahasa Indonesia. Jakarta: Gramedia Pustaka Utama.

Djajasudarma, T. Fatimah. 1993. Semantik 1: Pengantar ke Arah Ilmu Makna. Bandung: Eresco.

Djajasudarma, T. Fatimah. 1993. Semantik 2: Pemahaman Ilmu Makna. Bandung:Eresco.

Karim, Yurni dkk. 2013. Semantik Bahasa Indonesia. Tangerang: Pustaka Mandiri.

Kridalaksanan, Harimurti. 1993. Kamus Linguistik. Edisi Ketiga. Jakarta: Gramedia Pustaka Utama.

Lyons, Jons. 1977. Sematics Vol 1. Cambridge: Cambridge University Press.

Ogden, C.K. \& F.A. Richard. 1972. The Meaning of Meaning. London: Routledge dan Kegau Paul Ltd.

Pateda, Mansoer. 2001. Semantik Leksikal. Jakarta. Rineka Cipta.

Saussure, Ferdinand de. 1996. Pengantar Linguistik Umum. Diterjemahkan Rahayu S. Hidayat. Yogyakarta: Gadjah Mada University Press.

Soedjito. 1989. Sinonim. Bandung: Sinar Baru.

Tarigan, Henry Guntur. 1993. Pengajaran Semantik. Bandung: Angkasa

Ullmann. 1962. Semantics: An Introduction to the Science of Meaning. Diterjemahkan Sumarsono 1974. Semantik. Jakarta: Pusat Bahasa. 
Verhaar, J.W.M. 1992. Pengantar Linguistik. Yogyakarta: Gadjah Mada University Press.

http://www.wikipedia.org/wiki/sinonim. (Diunduh 30/6/2015)

http://www.persamaan kata.com.30661. (Diunduh 30/6/2015)

http://www.sinonim kata.com/sinonim 56087. (Diunduh 30/6/20115)

http://www.sinonim kata.com. (Diunduh 30/6/2015)

http://www. sinonim kata.com/sinonim 14866. (Diunduh 2/7/2015)

http://www. jonespandiangan.blogspot.com. (Diunduh 2/7/2015) 